\title{
Constraints to Effective Utilization of Information, Communication and Technology (ICT) in Technical Colleges in Rivers State, Nigeria
}

\author{
Nwauzi, Kelechi Kirian ${ }^{1 *}$, Divine O. Chiorlu ${ }^{2}$ \\ ${ }^{1}$ Department of Electrical/Electronics, School of Engineering Technology, Captain Elechi Amadi Polytechnics, Rumuola, Portharcourt, Nigeria \\ ${ }^{2}$ Department of Industrial Technical Education, Ignatius Ajuru University of Education, Rumuorlumini, Port Harcourt, Nigeria
}

DOI: $10.36348 /$ sjet.2021.v06i03.001

| Received: 03.03.2021 | Accepted: 20.03.2021 | Published: 25.03.2021

*Corresponding author: Nwauzi, Kelechi Kirian

\section{Abstract}

The study focused at the Constraints to effective Utilization of Information, Communication and Technology (CICT) in Technical Colleges in Rivers State. There are two purpose, research questions and hypotheses that guided the study. The study actually was carried out in Rivers State using a survey research design. The targeted population of the study was 1000 respondents which comprise 200 technical college teachers and 800 technical college students in Rivers State. A cluster sampling technique was used to divide the technical colleges into two clusters; the researcher further used random sampling technique to sample 50 technical college teachers and 200 students making the total sample of 250 respondents. A structured questionnaire was used to collect data for the study titled 'Constraints to effective Utilization of ICT Facilities in Technical College Questionnaire (CEUICTFTCQ), and instrument was face validated by three experts, Cronbach Alpha was used for reliability coefficient to determine the internal consistency of the instruments to give a value of 0.81. Findings of the study revealed that ICT skills are required in Technical Colleges in Rivers State. It was recommended that (1) since ICT facilities are available for usage, skills should be acquired with as to make use of the facilities provided, (2) Teachers and students of Technical colleges should be competent in the use of the facilities fully as to enhance their teaching- learning situation.

Keywords: Constraints, Communication and Technology, ICT Facilities.

Copyright ( $) 2021$ The Author(s): This is an open-access article distributed under the terms of the Creative Commons Attribution 4.0 International License (CC BY-NC 4.0) which permits unrestricted use, distribution, and reproduction in any medium for non-commercial use provided the original author and source are credited.

\section{INTRODUCTION}

In recent time, there has been increased interest in technical and vocational skills development because of precursory evidence that a country with better developed technical and vocational skills among the youth has higher likelihood to reduce poverty and lead to sustainable economic growth. In support, Harlt [1] argues that for a country to be successful, vocational and information and communication technology skills training have to take the distinctiveness of national and local labour markets and employability. The development of any nation hinges on the social and economic contributions of her citizens. Vocational and technical training plays a major role at promoting community and national development [2].

Vocational and technical education facilitates the acquisition of applied skills and basic scientific knowledge in ICT. It is a planned programme of course and learning experiences that begin with the exploration of career options, supports basic, academic and life skills, and enables the achievement of high academic standards, leadership, preparation for industry and continuing education. Therefore vocational and technical education involves the acquisition of techniques and the application of the knowledge of science for the improvement of man's surrounding. This includes dealing with manpower training in professional areas as engineering, agriculture, and business, home economics, and information and communication technology.

In Nigeria, the late President Musa Yar'Adua listed education among his seven point agenda that will guide his administration in the vision 20-2020 which was aimed at ensuring that Nigeria is placed among the leading 20 world economies by the year 2020 .

Hence, the Nigerian government agreed with the idea that the Information and Computer Technology (ICT) are able to enhance effectively education among the students. Thus the teacher and students have been encouraged to utilize the ICT facilities in education in teaching and learning process. The ICT development 
Nwauzi, Kelechi Kirian \& Divine O. Chiorlu., Saudi J Eng Technol, Mar, 2021; 6(3): 37-44

promised the immense potential in developing education to the students. ICT can be infused in students learning style which helps students to gain knowledge more effectively. ICT also can change student's ordinary study, the approach to get information, and knowledge sharing. Therefore, Ministry of Education River State has taken some strategies to integrate ICT in teaching and learning process in all category of school system over the state. No doubt that the ICT will help teachers to increase the student's academic achievement. Teachers are indispensable for successful learning about ICT, and learning and teaching through ICT. Computer education introduced into the Nigerian secondary school since 1988 has largely been unsuccessful as a result of teachers' incompetence [3].

The ICT developments also give benefits to the students in technical colleges especially in term of emerging the effectiveness of teaching and learning process. ICTs when utilized can enhance the quality of education in several ways: by increasing learner motivation and engagement, by facilitating the acquisition of basic skills, and by enhancing teacher training [4]. ICTs are also transformational tools which, when used appropriately, can promote the shift to a learner-centered environment. ICT when properly utilized can enhance the quality of technical college students in the area such as: motivation to learn; ICTs such as videos, television and multimedia computer software that combine text, sound, and colourful, moving images can be used to provide challenging and authentic content that will engage the student in the learning process and tele-collaboration. Interactive radio likewise makes use of sound effects, songs, dramatizations, comic skits, and other performance conventions to compel the students to listen and become involved in the lessons being delivered.

However, the question now becomes to what extent is ICT utilized in teaching and learning process in Rivers State technical colleges? Would the teachers and students prefer using ICT facilities in the teaching and learning process in Rivers State technical colleges? This gap in knowledge underscores the need to examine the constraints to effective utilization of ICT in Rivers State technical colleges. Therefore, there is need to investigate the constrints to effective utilization of ICT in Rivers State technical colleges.

\section{Statement of the problem}

There are a number of questions about the ICT acceptance and usage among teachers and students from technical colleges which emerge problem in technical colleges and affect the enrollment of the students. Constraints to effective utilization of Information, Communication and Technology (ICT) policy, as noted by Rowland [5] and cited in Hafkin [6], can be categorized into vertical, infrastructural, and horizontal policies. Vertical ICT policy addresses sectored needs, such as education, health and tourism.

The infrastructural aspect deals with the development of national infrastructure and this is closely linked with telecommunication. The horizontal aspect deals with the impact on broader aspects of society such as freedom of information, tariff and pricing, privacy and security. These three aspects area adequately addressed in the Nigerian IT policy. Federal Republic of Nigeria, [7] first, the mission statement recognized the need 'To Use IT for Education'. In addition, the general objectives stressed that information technology must be used to: empower the youth with IT skills and prepare them for global competitiveness, integrate IT into the mainstream of education and training, establish new multifaceted IT institutions as centers of excellence to ensure Nigeria's competitiveness in international markets, to develop a pool of IT engineers, scientists, technicians, and software developers; in order to increase the availability of trained personnel; to provide attractive career opportunities; and to develop requisite skills in various aspects of IT.

However, what exists in Rivers State technical colleges is a system where the technical college teachers will prefer to use teaching manuals, chalk boards and other teaching material that are not ICT inclined to teach the students. Students are only being prepared to acquire knowledge and skills for future jobs. The focus is only on learning about ICT, which is regarded as 'Topicality', whereas for technical colleges in Rivers State, the focus is regarded as the early stage of ICT use in education [8]. This philosophy limits the potential of ICT in education to a central force in economic competitiveness. Its potentials as a tool for addressing challenges in teaching and learning and as change agent are thus neglected [9]. Students need not learn about computers only; ICT should be integrated for the development and management of teaching and learning in Nigerian schools.

Base on this, the study tends to find out the constraints to effective utilization level of ICT in Rivers State technical colleges. Moreover the problem of this is what is the constraints to effective utilization level of ICT in Rivers State technical colleges.

\section{Purpose of the study}

The general purpose of the study is to assess the hindrances of ICT in Technical colleges in Rivers State. Specifically, the study seeks to find out:

1. The competency level students and teachers in the use of ICT facilities by technical college in Rivers State.

2. The skill level of the students in the use of ICT in technical colleges in River State.

\section{Significance of the study}

The findings of this study will probably be of benefit to technical college teachers, students, school administrators and curriculum planners. The findings of this study will also be of benefit to both government 
Nwauzi, Kelechi Kirian \& Divine O. Chiorlu., Saudi J Eng Technol, Mar, 2021; 6(3): 37-44

and private sectors as it enlighten them on how to provide ICT equipment and facilities in vocational and technical school for the acquisition of ICT skills. Moreover, it will encourage the government and other education stakeholders to make sure that ICT programmes at all levels of education are made relevant to provide youth and graduates' the needed ICT skills, Government should ensure adequate electricity supply in schools and Government should provide institutions at all levels in the country with adequate informationtechnology facilities. This can be achieve through attending regular seminars and workshops to keep teachers and students abreast of current ICT development in the field of vocational and technical education and how best to impact them on their students.

The findings of this study will be of immense benefit to Technical educators and teachers to involve ICT in technical and business organizations, the government, NGOs and successful industrialists in their service delivery to the students. A training plan that states clearly what the student is expected to learn and what the employer is expected to provide, should be developed as an integral part of national strategy. Teachers should be more committed to teaching with the use of ICT-driven instructional aids given the importance of practical knowledge in it. This can be achieve through attending regular seminars and workshops to keep teachers and students abreast of current ICT development in the field of vocational and technical education and how best to impact them on their students.

The study will encourage the need to review our educational policy strategies and techniques as well as the teaching methodologies of developing our teachers. It will also introduce the teaching of ICT in the school curricular at all levels of our educational system with emphasis on practical application. Hence, ICT as a course should be made compulsory for teachers and students of technical colleges as these students will graduate to teach our school children in schools. This study would help to reposition the teaching profession in Nigeria in the preparation of teachers in technical colleges in Rivers State with emphasis placed on adequate knowledge and application of ICT in teaching -learning process in their teacher education programmes. The study will encourage the urgent need for the training and retraining of all teachers in technical colleges on the use of ICT in classroom teaching while the governments at local, state and federal levels should pay adequate attention to the provision of ICT facilities in our various schools in a bid to create an enabling environment that could help the teachers to perform optimally. Regular seminars and workshops should be organized to keep teachers abreast of current development in the field of vocational and technical education and how best to impact them on their students.

\section{RESEARCH QUESTIONS}

Two research questions were posed to guide the study:

1. What are the competency level in the use of ICT facilities by technical college teachers and students in Rivers State?

2. What is the skill level of students in the use of ICT in technical colleges in Rivers State?

\section{HYPOTHESES}

Two hypotheses were posed to guide the study and will be tested at $0.05 \%$ level of significance.

1. There is no significant difference in the mean ratings of teachers and students on the competency level of ICT facilities usage in technical college in River State

2 There is no significant difference in the mean ratings of teachers and students on the level of skills of students in the use of ICT in technical colleges in Rivers State.

\section{Delimitation of the study}

The study is delimited to the Hindrances in the use of ICT in Technical colleges in Rivers State geographical location. The topic chosen from the study is Hindrances in the use of Information, Communication and Technology under which the following sub-topics will be covered: the level of students' on the use of ICT in technical colleges in Rivers State, the skill level of the students in the use of ICT in technical colleges in River State.

\section{Materials and methods}

This chapter presents a description of the method adopted for the study under the following subheadings: the design of the study, area of the study, population for the study, sample and sampling technique, instrument for data collection, validation of the instrument, reliability of the instrument, method of data collection, and method of data analysis.

\section{Design of the study}

This study adopted a survey research design. According to Gall, Gall and Borg [12], a survey research is a method of data collection in which questionnaires or interview is utilized in collecting data from a sample that has been selected to represent a population to which the findings of the data analysis can be generalized. The survey research design is considered suitable because the study elicited data/information on records-keeping practice needs of the entrepreneurs of small scale business enterprise in Port Harcourt metropolis.

\section{Area of the study}

The study was carried out in Rivers State. Rivers State is one of the States in South-South Geopolitical Zone. It has boundary with Abia, Bayelsa and Imo States. The State has 23 local government areas with eight ethnic groups. The state has more technical and oil servicing industries that can make use 
Nwauzi, Kelechi Kirian \& Divine O. Chiorlu., Saudi J Eng Technol, Mar, 2021; 6(3): 37-44

of these technical graduates. The technical colleges in the state have more students and teachers who can form the population to be used in the research. There are only three technical colleges in the state. The study was conducted in the three technical colleges in the State. The rationale for choosing these colleges is based on the fact that they have ICT facilities and these facilities are within the school premises.

\section{Population of study}

The target population of the study is 1000 respondents, comprising 200 technical college teachers and 800 technical college students in Rivers State.

\section{Sample and sampling techniques}

Cluster sampling technique was used to divide the technical colleges into two clusters group; the researcher further used random sampling technique to sample 50 technical college teachers and 200 students making the total sample of 250 respondents.

\section{Instrument for data collection}

A structured questionnaire was used to collect data for this study titled 'Constraints to Effective Utilization of ICT Facilities in Technical Colleges Questionnaire (CEUICTFTCQ). The instrument was developed after the review of relevant literature on the constraints to effective use of ICT facilities in technical colleges. The instrument contains two sections A-B. Section A elicited data on the students' level of ICT usage in technical colleges in Rivers State. Section B elicited data on the hindrances to the usage of ICT in technical colleges in Rivers State.

\section{Validation of the instrument}

The instrument was face-validated by three experts from the Department of Industrial Technical Education, University of Nigeria, Nsukka. The validators were requested to read through the questionnaire items in terms of clarity and appropriateness based on the research questions for the study under investigation. The validators comment and suggestions were utilized to structure the instrument.

\section{Reliability of the instrument}

To establish the reliability of the instrument, 30 copies of the questionnaires was trial-tested among the technical college students and teachers in Bayelsa State technical college, hence this did not form the part of the main population for the study. Cronbach Alpha reliability coefficient formula was used to determine the internal consistency of the instruments to give a value of 0.81 .

\section{Method of data collection}

The researcher administered the questionnaire personally together with the help of two research assistants. The researcher informed the research assistants on the procedures required in administering the questionnaire. The completed copies of the questionnaire were also retrieved by the researcher and the two research assistants within a week to help maximize the return rate of the questionnaire for data analysis.

\section{Method of data analysis}

Section A of the instrument was analyzed using percentage and frequency count. Any item with a frequency below 50 percent was regarded as not available and any item with a frequency count above 50 percent was regarded as available. Section B was analyzed using mean and standard deviation to answer the three research questions. T-test was used to test the null hypotheses at 0.05 probability level of significance. Decision was taken as follows: if the calculated value is greater or equal to the table value, the null hypothesis was rejected. On the other hand if the calculated value is less than the table value, the null hypothesis was not rejected.

\section{Research question one}

What is the teachers and students competency level in the use of ICT facilities in technical college in Rivers State?

Table-1: Mean and Standard Deviation Responses of Teachers and Students competency level of ICT facility usage in Technical Colleges in River State.

\begin{tabular}{|c|l|c|c|c|c|}
\hline S/N & \multicolumn{1}{|c|}{ Item Statement } & $\mathbf{N}$ & SD & Dec \\
\hline 1 & $\begin{array}{l}\text { Teachers and students know the basic function of computer hardware components } \\
\text { (CPU and monitor) including other parts like printer, speaker and mouse. }\end{array}$ & 318 & 3.98 & 0.14 & HL \\
\hline 2 & Teachers and students know how to log in to the internet service provider (ISP). & 318 & 3.95 & 0.22 & HL \\
\hline 3 & They know how to navigate the web pages (go to next or previous page) & 318 & 4.78 & 0.43 & VHL \\
\hline 4 & They know how to access an online library and other resource database. & 318 & 3.96 & 0.19 & HL \\
\hline 5 & Teachers and students have attended online classes before & 318 & 3.79 & 0.41 & HL \\
\hline 6 & They can use file compression & 318 & 4.58 & 0.81 & HL \\
\hline 7 & They likes teaching new technologies & 318 & 3.98 & 0.14 & HL \\
\hline 8 & Have an email addresses & 318 & 3.98 & 0.15 & HL \\
\hline 9 & They open/send email with file attachments & 318 & 3.19 & 0.39 & ML \\
\hline 10 & They know how to download files using any browser & 318 & 3.98 & 0.13 & HL \\
\hline 11 & They have attended online classes before & 318 & 3.77 & 0.42 & HL \\
\hline & Cluster Mean & $\mathbf{3 1 8}$ & $\mathbf{3 . 9 9}$ & $\mathbf{0 . 3 1}$ & $\begin{array}{c}\text { High } \\
\text { Level }\end{array}$ \\
\hline
\end{tabular}

Note: $\mathrm{N}=$ Number of Respondents, $\bar{x}=$ Mean, $\mathrm{SD}=$ Standard Deviation, Dec. $=$ Decision 
The result in Table 1 shows mean and standard deviation of respondents on the level of usage of ICT by students' in technical colleges in Rivers State. Result showed that items 1, 2, 4-8, and 10-11 which had mean of $3.98,3.95,3.96,3.79,3.98,3.98,3.98$ and 3.77 with standard deviations of $0.14,0.22,0.19,0.41,0.81,0.14$, $0.15,0.13$, and 0.42 respectively. This means that the respondents show high level of usage of ICT by students' in technical colleges in Rivers State. Also, result on items 3 had mean ratings of 4.78 with standard deviations of 0.43 respectively which showed very high level of usage of ICT by students' in technical colleges in Rivers State but moderate level for item 9 with mean of 3.19 and standard deviation of 0.39 . The cluster mean of 3.99 with standard deviation of 0.31 high level of usage of ICT by students' in technical colleges in Rivers State.

\section{Hypothesis one}

There is no significant difference in the mean responses of teachers and students on the level of usage of ICT facilities by technical college students' in River State.

Table -2: T-test Analysis of Significant Difference in the Mean Responses of Teachers and Students on the use of ICT Facilities in Technical Colleges in Rivers State.

\begin{tabular}{|c|c|c|c|c|c|c|c|c|}
\hline $\mathbf{S} / \mathbf{N}$ & Item Statement & Status & $\overline{\bar{x}}$ & SD & t-cal & Df & Sig. & Dec \\
\hline 1 & $\begin{array}{l}\text { Teachers and Students know the basic } \\
\text { function of computer hardware } \\
\text { components (CPU and monitor) } \\
\text { including other parts like printer, } \\
\text { speaker and mouse. }\end{array}$ & $\begin{array}{l}\text { Teacher } \\
\text { Student }\end{array}$ & $\begin{array}{l}3.90 \\
4.00\end{array}$ & $\begin{array}{l}0.30 \\
0.00\end{array}$ & 144.21 & 316 & 0.00 & $\mathrm{~S}$ \\
\hline 2 & $\begin{array}{l}\text { Teachers and Students know how to } \\
\text { log in to the internet service provider } \\
\text { (ISP). }\end{array}$ & $\begin{array}{l}\text { Teacher } \\
\text { Student }\end{array}$ & $\begin{array}{l}3.78 \\
3.99\end{array}$ & $\begin{array}{l}0.42 \\
0.11\end{array}$ & 252.59 & 316 & 0.00 & $\mathrm{~S}$ \\
\hline 3 & $\begin{array}{l}\text { They know how to navigate the web } \\
\text { pages (go to next or previous page). }\end{array}$ & $\begin{array}{l}\text { Teacher } \\
\text { Student }\end{array}$ & $\begin{array}{l}3.97 \\
4.97\end{array}$ & $\begin{array}{l}0.00 \\
0.39\end{array}$ & 0.01 & 316 & 0.91 & $\mathrm{~S}$ \\
\hline 4 & $\begin{array}{l}\text { They know how to access an online } \\
\text { library and other resource database. }\end{array}$ & $\begin{array}{l}\text { Teacher } \\
\text { Student }\end{array}$ & $\begin{array}{l}3.87 \\
3.98\end{array}$ & $\begin{array}{c}0.220 \\
21\end{array}$ & 83.34 & 316 & 0.00 & NS \\
\hline 5 & $\begin{array}{l}\text { They have attended online classes } \\
\text { before }\end{array}$ & $\begin{array}{l}\text { Teacher } \\
\text { Student }\end{array}$ & $\begin{array}{l}3.05 \\
3.97\end{array}$ & $\begin{array}{l}0.00 \\
0.11\end{array}$ & 1.20 & 316 & 0.27 & NS \\
\hline 6 & They can use file compression & $\begin{array}{l}\text { Teacher } \\
\text { Student }\end{array}$ & $\begin{array}{l}3.05 \\
4.93\end{array}$ & $\begin{array}{l}0.00 \\
0.21\end{array}$ & 0.75 & 316 & 0.39 & NS \\
\hline 7 & They likes teaching new technologies & $\begin{array}{l}\text { Teacher } \\
\text { Student }\end{array}$ & $\begin{array}{l}3.93 \\
3.99\end{array}$ & $\begin{array}{l}0.00 \\
0.22\end{array}$ & 38.70 & 316 & 0.00 & $\mathrm{~S}$ \\
\hline 8 & Have an email addresses & $\begin{array}{l}\text { Teacher } \\
\text { Student }\end{array}$ & $\begin{array}{l}3.92 \\
3.99\end{array}$ & $\begin{array}{l}0.59 \\
0.22\end{array}$ & 56.87 & 316 & 0.00 & $S$ \\
\hline 9 & $\begin{array}{l}\text { They open/send email with file } \\
\text { attachments }\end{array}$ & $\begin{array}{l}\text { Teacher } \\
\text { Student }\end{array}$ & $\begin{array}{l}3.88 \\
3.02\end{array}$ & $\begin{array}{l}0.48 \\
0.37\end{array}$ & 44.31 & 316 & 0.00 & $\mathrm{~S}$ \\
\hline 10 & $\begin{array}{l}\text { They know how to download files } \\
\text { using any browser }\end{array}$ & $\begin{array}{l}\text { Teacher } \\
\text { Student }\end{array}$ & $\begin{array}{l}3.93 \\
4.00\end{array}$ & $\begin{array}{l}0.00 \\
0.37\end{array}$ & 55.37 & 316 & 0.00 & $\mathrm{~S}$ \\
\hline 11 & $\begin{array}{l}\text { They have attended online classes } \\
\text { before }\end{array}$ & $\begin{array}{l}\text { Teacher } \\
\text { Student }\end{array}$ & $\begin{array}{l}3.00 \\
3.95\end{array}$ & $\begin{array}{l}0.49 \\
0.00\end{array}$ & 12.86 & 316 & 0.00 & $\mathrm{~S}$ \\
\hline & Cluster $\mathbf{t}$ & $\begin{array}{l}\text { Teacher } \\
\text { Student }\end{array}$ & $\begin{array}{l}3.66 \\
4.07\end{array}$ & $\begin{array}{l}0.98 \\
0.96\end{array}$ & 9.73 & 316 & 0.00 & $\mathbf{S}$ \\
\hline
\end{tabular}

Result in Table 2 reveals that there was a significant difference on items 1-3 and 7-11. This is because their significant or probability values are less than 0.05 set as level of significance for testing the null hypotheses. However, there was no significant difference on items 4 to 6 this is because their probability or significance values are greater than 0.05 set as level of significance. The cluster t-value of 9.73 with a degree of freedom of 316 and a significant value of 0.00 means that the null hypothesis of no significant difference in the mean ratings of teachers and students on the usage of ICT facilities by technical college students' in Rivers State is rejected. Inference drawn is that there is significant difference in the mean ratings of teachers and students on the usage of ICT facilities by technical college students' in Rivers State.

\section{Research question two}

What is the skill level of students in the use of ICT in technical colleges in Rivers State? 
Nwauzi, Kelechi Kirian \& Divine O. Chiorlu., Saudi J Eng Technol, Mar, 2021; 6(3): 37-44 Table-3: Mean and Standard Deviations of the respondents on the skill level of students in the use of ICT in Technical Colleges in Rivers State

\begin{tabular}{|c|l|c|c|c|c|}
\hline S/N & \multicolumn{1}{|c|}{ Items } & $\mathbf{N}$ & $\overline{\boldsymbol{x}}$ & SD & Dec. \\
\hline 1 & ICT tools are changing too fast to keep current & 318 & 3.52 & 0.84 & SA \\
\hline 2 & Certain software is difficult to learn and use & 318 & 3.56 & 0.83 & SA \\
\hline 3 & The hardware available are not sufficient to accommodate ICT supported teaching & 318 & 3.36 & 1.19 & A \\
\hline 4 & The software available are not sufficient to accommodate ICT supported teaching & 318 & 3.35 & 1.21 & A \\
\hline 5 & $\begin{array}{l}\text { The administrators (management) do not provide any clear instruction on how to } \\
\text { integrate ICT tools in teaching-learning }\end{array}$ & 318 & 3.55 & 0.83 & SA \\
\hline 6 & The management do not initiate any program to encourage ICT supported teaching & 318 & 3.35 & 1.21 & A \\
\hline 7 & $\begin{array}{l}\text { There is no long term staff development to support the integration of technology } \\
\text { into instruction. }\end{array}$ & 318 & 4.32 & 1.21 & SA \\
\hline 8 & $\begin{array}{l}\text { The hardware available is already outdated to accommodate ICT supported } \\
\text { teaching-learning }\end{array}$ & 318 & 4.32 & 1.24 & SA \\
\hline 9 & The network connectivity is poor. & 318 & 3.59 & 0.78 & SA \\
\hline 10 & Students lack ICT skills & 318 & 2.00 & 0.19 & D \\
\hline 11 & Management do not have any vision on integration of ICT tools in teaching & 318 & 2.78 & 0.44 & A \\
\hline & Cluster mean & $\mathbf{3 1 8}$ & $\mathbf{3 . 4 3}$ & $\mathbf{0 . 9 1}$ & $\mathbf{A}$ \\
\hline
\end{tabular}

Key: $\mathrm{N}=$ Number of respondents, $\bar{x}=$ mean, $\mathrm{SD}=$ Standard Deviation, Dec. $=$ Decision

Result presented in Table 3 showed the mean and standard deviations of respondents on the hindrances to the usage of ICT in technical colleges in Rivers State. Result showed that items 1-2, 5, and 7-9 had mean of $3.52,3.56,3.55$ and 4.32, 4.32, 3.59 with standard deviations of $0.84,0.83,0.83$ and $1.21,1.24$, 0.78 respectively. These mean are above the criterion level of 3.50 set for accepting an item; this means that the respondent strongly agreed on hindrances to the usage of ICT in technical colleges in Rivers States. Meanwhile, items 3-4, 6, and 11 had mean of 3.36, $3.35,3.35$ and 2.78 with standard deviations of 1.19 , $1.21,1.21$ and 0.44 respectively. These mean are above are between the criterion level of $2.50-3.50$ set for accepting an item, this means that the respondents Agreed on hindrances to the usage of ICT in technical colleges in Rivers States. On the other hand, the mean of 2.00 with standard deviation 0.19 show that respondent disagrees on hindrances to the usage of ICT in technical colleges in Rivers state. The clustered mean of 3.43 with a standard deviation of 0.91 showed that the respondents agreed that there are constraints to effective use to of ICT in technical colleges in Rivers state. Therefore, evidence showed that Students had ICT skills but, there are constraints to effective use of ICT facilities in the technical Colleges in River State.

\section{Hypothesis two}

There is no significant difference in the mean responses of teachers and students on hindrances to the usage of ICT in technical colleges in Rivers State

Table-4: t-test Analysis of the Significant Difference in the Mean Responses of Teachers and Students on the skill level of students in the use of ICT in Technical Colleges in Rivers State

\begin{tabular}{|c|c|c|c|c|c|c|c|c|}
\hline $\mathbf{S} / \mathbf{N}$ & Item Statement & Status & $\bar{x}$ & SD & t-cal & Df & Sig & Dec \\
\hline 1 & ICT tools are changing too fast to keep current & $\begin{array}{l}\text { Teacher } \\
\text { Student }\end{array}$ & $\begin{array}{l}2.00 \\
3.88\end{array}$ & $\begin{array}{l}0.00 \\
0.45\end{array}$ & 0.91 & 316 & 0.00 & $\mathrm{~S}$ \\
\hline 2 & Certain software is difficult to learn and use & $\begin{array}{l}\text { Teacher } \\
\text { Student }\end{array}$ & $\begin{array}{l}2.003 . \\
92\end{array}$ & $\begin{array}{l}0.00 \\
0.38\end{array}$ & 11.93 & 316 & 0.01 & $\mathrm{~S}$ \\
\hline 3 & $\begin{array}{l}\text { The hardware available are not sufficient to accommodate } \\
\text { ICT supported teaching }\end{array}$ & $\begin{array}{l}\text { Teacher } \\
\text { Student }\end{array}$ & $\begin{array}{l}1.10 \\
3.88\end{array}$ & $\begin{array}{l}0.31 \\
0.52\end{array}$ & 0.53 & 316 & 0.47 & S \\
\hline 4 & $\begin{array}{l}\text { The software available are not sufficient to accommodate } \\
\text { ICT supported teaching }\end{array}$ & $\begin{array}{l}\text { Teacher } \\
\text { Student }\end{array}$ & $\begin{array}{l}1.07 \\
3.88\end{array}$ & $\begin{array}{l}0.25 \\
0.55\end{array}$ & 2.14 & 316 & 0.14 & NS \\
\hline 5 & $\begin{array}{l}\text { The administrators (management) do not provide any clear } \\
\text { instruction on how to integrate ICT tools in teaching- } \\
\text { learning }\end{array}$ & $\begin{array}{l}\text { Teacher } \\
\text { Student }\end{array}$ & $\begin{array}{l}2.00 \\
3.91\end{array}$ & $\begin{array}{l}0.00 \\
0.39\end{array}$ & 13.84 & 316 & 0.00 & $\mathrm{~S}$ \\
\hline 6 & $\begin{array}{l}\text { The management do not initiate any program to encourage } \\
\text { ICT supported teaching }\end{array}$ & $\begin{array}{l}\text { Teacher } \\
\text { Student }\end{array}$ & $\begin{array}{l}1.07 \\
3.88\end{array}$ & $\begin{array}{l}0.25 \\
0.53\end{array}$ & 2.29 & 316 & 0.14 & NS \\
\hline 7 & $\begin{array}{l}\text { There is no long term staff development to support the } \\
\text { integration of technology into instruction. }\end{array}$ & $\begin{array}{l}\text { Teacher } \\
\text { Student }\end{array}$ & $\begin{array}{l}2.07 \\
4.84\end{array}$ & $\begin{array}{l}0.25 \\
0.58\end{array}$ & 5.85 & 316 & 0.16 & NS \\
\hline 8 & $\begin{array}{l}\text { The hardware available is already outdated to } \\
\text { accommodate ICT supported teaching-learning }\end{array}$ & $\begin{array}{l}\text { Teacher } \\
\text { Student }\end{array}$ & $\begin{array}{l}2.00 \\
4.86\end{array}$ & $\begin{array}{l}0.00 \\
0.58\end{array}$ & 15.05 & 316 & 0.00 & $\mathrm{~S}$ \\
\hline 9 & The network connectivity is poor & $\begin{array}{l}\text { Teacher } \\
\text { Student }\end{array}$ & $\begin{array}{l}2.12 \\
3.93\end{array}$ & $\begin{array}{l}0.32 \\
0.33\end{array}$ & 2.95 & 316 & 0.09 & NS \\
\hline 10 & Students lack ICT skills & $\begin{array}{l}\text { Teacher } \\
\text { Student }\end{array}$ & $\begin{array}{l}2.00 \\
2.00\end{array}$ & $\begin{array}{l}0.00 \\
0.21\end{array}$ & 2.16 & 316 & 0.14 & NS \\
\hline 11 & $\begin{array}{l}\text { Management do not have any vision on integration of ICT } \\
\text { tools in teaching }\end{array}$ & $\begin{array}{l}\text { Teacher } \\
\text { Student }\end{array}$ & $\begin{array}{l}2.05 \\
2.95\end{array}$ & $\begin{array}{l}0.22 \\
0.26\end{array}$ & 0.23 & 316 & 0.63 & NS \\
\hline & Cluster $\mathbf{t}$ & $\begin{array}{l}\text { Teacher } \\
\text { Student }\end{array}$ & $\begin{array}{l}3.77 \\
3.81\end{array}$ & $\begin{array}{c}0.07 \\
0.38\end{array}$ & 4.18 & 316 & 0.04 & $\mathbf{S}$ \\
\hline
\end{tabular}

(C) 2021 | Published by Scholars Middle East Publishers, Dubai, United Arab Emirates 
Result in Table 4 reveals that there is a significant difference between the mean response of respondents from teachers and students on hindrances to the usage of ICT in technical colleges in Rivers State Technical Colleges. There was a significant difference on items 1-3, 5 and 8 . This is because their significant or probability values are less than 0.05 set as level of significance for testing the null hypotheses. However, there was no significant difference on items $4,6,7$, and 9-11 this is because their probability or significance values are greater than 0.05 set as level of significance. The cluster t-value of 4.18 with a degree of freedom of 316 and a significant value of 0.04 means that the null hypothesis of no significant difference in the mean ratings of teachers and students on hindrances to the usage of ICT in technical colleges in Rivers State Technical Colleges is rejected. Inference drawn from the responses of teachers and students in technical colleges of river state had different views on the on hindrances to the usage of ICT.

\section{Findings of The Study}

The following findings emerged from the study based on the purpose of the study:

\section{The competency level of teachers and students} on the use of ICT in technical colleges in Rivers State

Some items showed high level and very high level of usage of ICT by students' in technical colleges in Rivers State. While, the cluster mean showed high level of usage of ICT by students' in technical colleges in Rivers State. Moreso, result on cluster t-value drawn showed significant difference exist in the mean responses of teachers and students on the usage of ICT facilities by technical college students' in Rivers State.

\section{The skill level of students to the use of ICT in technical colleges in River State}

Findings showed that the respondents Agreed on constraints to effective use of ICT in technical colleges in Rivers state. Therefore, finding showed that Students does not lack ICT skills but, there are constraints to effective use of ICT facilities in the technical Colleges in River State. However, the cluster t-value drawn showed that significance differences exist between the responses of teachers and students in technical colleges of river on constraints to effective use of ICT facilities.

\section{DISCUSSION OF THE FINDINGS}

The findings of the study are discussed in relation to the research questions and the null hypotheses that guided the study.

\section{The competency level of teachers and students on the use of ICT facilities in technical colleges in Rivers State}

The cluster mean showed high level of usage of ICT by students' in technical colleges in Rivers
State. Moreso, result on cluster t-value drawn showed significant difference exist in the mean responses of teachers and students on the usage of ICT facilities by technical college students' in Rivers State.

Mohd, Baharom, and Mohd [10] carried out a study on Information and Communication Technology (ICT) Usage in Technical and Vocational Special Education Programme. The respondents of research were teachers and students from three different of Vocational Special Education Secondary School in Malaysia. The study corrobates with the current study on the use of ICT facilities by technical college students'.

The skill level of students to the use of ICT in technical colleges in River State

Findings showed that the respondents Agreed on the skill level of students to the usage of ICT in technical colleges in Rivers state. Therefore, finding showed that Students does not lack ICT skills but, there are constraints to the usage of ICT facilities in the technical Colleges in River State. However, the cluster $\mathrm{t}$-value drawn showed that significance differences exist between the responses of teachers and students in technical colleges of river on constraints to the use of ICT.

This current study agreed with the view of Adeshina, Udoh, Ndomi, and Aliyu, [11] on the Impact of Information Technology Skills on Old and New Generation Secretarial Teachers in Nigeria Colleges of Education to Utilize Internet for Classroom Delivery. This study established the difference between the old generation and new generation secretarial Teachers in Nigerian Colleges of Education and their ability to utilize Information Technology skills to access information from the internet for classroom delivery.

\section{MAJOR FINDINGS OF THE STUDY}

The major findings of this study are summarized as follows;

1. The result on cluster t-value drawn showed significant difference exist in the mean responses of teachers and students on the competency level of ICT facility usage in technical college in Rivers State.

2. However, the cluster t-value drawn showed that significant difference exists in the mean responses of students in technical colleges of River state on their skill level to the use of ICT.

\section{CONCLUSION}

The purpose of this study was to assess the constraints to effective utilization of ICT in Technical colleges in Rivers State. Data were collected, analyzed and interpreted. Based on the findings of the study, effort should be made towards ensuring the availability of ICT facilities like: Data- base, Cyber Cafes, Multimedia projector, Laptops, TV/Radio projector, 
Nwauzi, Kelechi Kirian \& Divine O. Chiorlu., Saudi J Eng Technol, Mar, 2021; 6(3): 37-44

Still/Digital camera, Video Recorder E-mail, Resources, Networking with other library and information systems and Local Area Network for library in very high frequency and very high percentage. E-library and Digital library facilities which were not available for usage in technical Colleges in Rivers State should be made available at a higher frequency and percentage. Moderate Level of ICT facilities usage should be raised by technical College teachers' in Rivers States. Since the result was evident that the usage of ICT facilities by students' in technical colleges in Rivers State was at high level, therefore teacher should encourage the students on the usage of ICT facilities in technical Colleges in Rivers States. Also, constraints to effective use of ICT in technical colleges in Rivers state should be discouraged since the respondents agreed that there are constraints to the use of ICT facilities in the Rivers state.

\section{RECOMMENDATIONS}

1. The relevant ICT facilities should be made available and students of the technical college should be fully involved in the usage of the facilities to enhance their skill.

2. Constraints to the use of ICT facilities by students in technical colleges in Rivers state should be removed as to give students access to the ICT facilities.

\section{REFERENCE}

1. Harlt, M.D. (2009). Information technology and sustainable development in Nigeria.Nigerian Journal of Science and Environmental Education, 1(1) 178- 183.

2. Oguntuyi, A. (2004). "An Evaluation of the National Teachers Institute.opinions of the teachers and principals of primary and secondary schools in Turkey. Journal of Instructional Science and Technology organizational change. Retrieved from http://www.artnodes.com/ojs/index.php/rusc/article /view/v5n1-benyoussef-dahmani/v5n1-benyoussef-dahmani.

3. Yusuf, M. O. (1998). Information and Communication Technology and Education: Analysing the Nigerian National Policy for Information Technology. International Education Journal, 2005, 6(3), 316-321.
4. Haddad, W., \& Jurich, S. (2002). ICT for education: Potential and potency. Technologies for education: Potential, parameters and prospects. UNESCO and Academy for Educational Development, 28-40.

5. Rowland, R. S., \& Taylor, R. (1996). Intermolecular nonbonded contact distances in organic crystal structures: Comparison with distances expected from van der Waals radii. The Journal of Physical Chemistry, 100(18), 73847391.

6. Hafkin, M. J. (2002). "Learning in open-ended environments: assumptions, methods and implications". Educational Technology, 34(8) 4855.

7. Federal Government of Nigeria (2004).National policy on education. Revised Edition. Federal Ministry of Education, Abuja, Nigeria.

8. Cloke, C., \& Sharif, S. (2001). Why use information and communication technology in schools? Key Building Blocks for Student Achievement in the 21st Century: Integrating Digital Content. Washington, DC: Author. Available at: http://www.ceoforum.org/downloads/report4.pdf

9. Culp, K. M., Honey, M., \& Mandinach, E. (2003). A Retrospective in Twenty Years ofcurrent and future use of ICT in higher education. Retrieved from http://www.utwente.nl/mb/cheps/phdportal/cheps\% 20alumni\%20and\%

10. Mohd. Yusoff, Y., Shah Abdullah, H., \& Baharom, A. (2010). HRM effectiveness within the role of HRM department at the large companies in Malaysia. International Journal of Business and Management Science, 3(1), 1-16.

11. Adeshina. (2013). Information and communication technology (ICT) resources for teaching agricultural economics in schools.Journal of Research in Vocational and Technical Education, 3(1) 23- 29.

12. Gall, M. D., Gall, J. P., Borg, W. R., \& Mendel, P. C. (2007). A guide for preparing a thesis or dissertation proposal in education, for Gall, Gall, and Borg'Educational research: an introduction'and' Applying Educational Research'. Pearson Education. 